\title{
UK accused over risk of CJD in plasma...
}

[PARIS] Foot-dragging by the British government is exposing haemophiliacs to an avoidable risk of infection with the new variant of Creutzfeldt-Jakob disease (vCJD) from contaminated blood products. That was the warning issued last week by the organization that represents the directors of 109 centres that treat haemophilia and other complex blood diseases.

The government has acknowledged that blood products pose a potential risk of transmission. But it has so far limited action to commissioning a detailed risk assessment of the problem, and asking the National Blood Authority to consider removing lymphocytes from the blood, given that the causative agent of vCJD may occur in these and other lymphoreticular tissues (see Nature 390, 105; 1997).

In a letter to The Lancet, however, the UK Haemophilia Centre Directors' Organization says the potential risk is already obvious. It calls for immediate action to protect haemophiliacs by switching them from blood products prepared from UK plasma

supplies to either recombinant alternatives or products prepared from donor plasma collected in countries with no recorded cases of bovine spongiform encephalopathy (BSE) or vCJD.

Christopher Ludlam, the chairman of the organization, says the letter is an attempt to draw attention to what he characterizes as a ludicrous situation - that, whereas the European Agency for the Evaluation of Medicinal Products' (EMEA) Committee for Proprietary Medicinal Products has recommended that plasma from donors with vCJD should not be used, the absence of a diagnostic test for vCJD means it is impossible to screen donors.

Given the high level of exposure of the UK population to BSE during the 1980s, and the long incubation period of spongiform encephalopathies, many seemingly healthy donors may be harbouring the disease.

The potential risk for haemophiliacs is much higher than for other transfused patients, as they receive multiple transfusions of products prepared from pools of

\section{...and latest BSE beef ban 'comes too late'}

[PARIS] Repeated assurances by the UK government that British meat is now safe to eat came to an abrupt end last week when it banned the sale of all cuts of beef on the bone on the grounds of new scientific evidence showing infectivity in bone tissues. The ban includes Tbone steaks, ribs and oxtail.

The government acknowledged last March that the agent that causes bovine spongiform encephalopathy (BSE) might pass to humans (see Nature $380,273 ; 1995)$. But the official line has been that a 1990 ban on consumption of specified bovine offals has been sufficient to protect the population, and that reported cases of the new variant of Creutzfeldt-Jakob disease would have been caused by consumption of such tissues before that date.

But, according to the government's Spongiform Encephalopathy Advisory Committee (SEAC), research by the Ministry of Agriculture, Fisheries and Food in which cattle were fed BSE- contaminated tissues has also revealed infectivity in dorsal root ganglia, trigeminal ganglia and bone marrow.

The ban on beef on the bone was hastily announced by Jack Cunningham, the agriculture minister, after SEAC's advice to the government was leaked to the press. But it is likely to have little impact on public health. According to SEAC's own estimates, as BSE is now dying out in British herds, only about six of the 2.2 million cattle expected to be slaughtered next year are likely to be infective.

Stephen Dealler, a UK BSE researcher, is one of many scientists who argue that the research results are largely "of historical interest, in that they tell us what we have been eating". They argue that the latest ban confirms that the government decision-making process in the BSE crisis has focused on responding retrospectively to firm scientific results rather than taking sufficient precautions against anticipated potential risks - such as that to haemophiliacs (see above).

This issue is likely to come under scrutiny as part of the inquiry into the former Conservative government's handling of the BSE crisis which the new Labour government announced last week. One question will be the basis of previous assurances on the safety of beef on the bone.

Mark Savay, a French BSE researcher, points out that the choice of cattle tissues originally banned in the United Kingdom and Europe was based not on direct experimental evidence of their infectivity, but on the known distribution of scrapie infectivity in sheep.

Savay points out that the European Commission banned exports of UK beef on the bone in 1990, except where it originated from herds where BSE had not been reported for two years. "What is extraordinary is that the same logic should have been applied to UK consumers but it wasn't," he says. D. B.

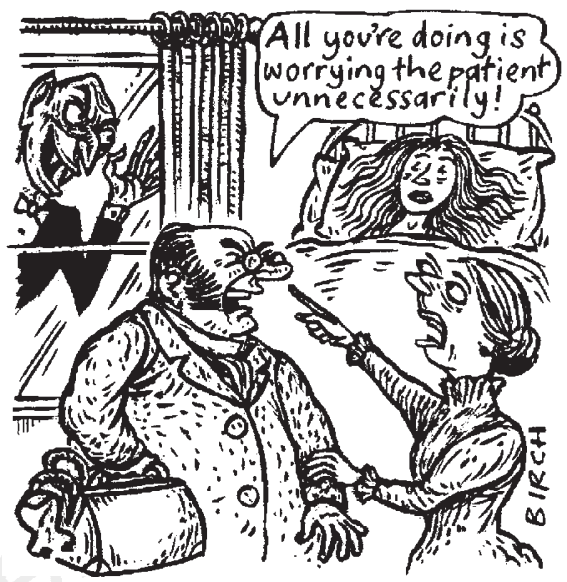

plasma derived from 20,000 to 50,000 individual donations. "There is therefore obviously a much increased risk of getting at least one infected donation in the pool, and one batch of factor VIII may go to 50 haemophiliacs," says Ludlam.

Most haemophiliacs in many countries — including France and Ireland — already exclusively use recombinant factor VIII on the grounds that it is completely safe. But the UK Department of Health has rejected the recommendation of the directors of haemophilia centres that Britain should eliminate all risk of vCJD transmission to haemophiliacs by simply following suit. The department argues that it is up to local authorities to decide. In a statement released last week the health department described the directors' alert as worrying patients unnecessarily.

John Purves, a spokesman for the EMEA, says the agency intends to convene an expert meeting on the problem early next year, which is likely to yield new recommendations. The arguments in the letter to The Lancet will be "taken into account", he says.

Local authorities are reluctant to switch to recombinant products because they are more expensive. But the difference in price results largely from the fact that recombinant products are subject to UK value-added tax whereas plasma-derived products are not.

"The net cost of the UK going over to

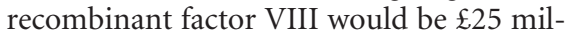
lion (US\$42 million)," estimates Ludlam. He says this is a pittance compared with the

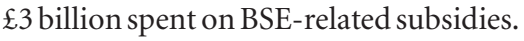

Ludlam's frustration is shared by many researchers who feel that the risk from blood products is receiving insufficient attention. "I took part in the discussion in the early 1980s over HIV and blood, and I have that awful sinking feeling all over again; the issues are so similar," says Ludlam. "All we need is one haemophiliac to get $\mathrm{VCJD}$ and all blood products will be removed from the market."

DeclanButler 